\title{
Emerging strategies and therapies for treatment of Paget's disease of bone
}

This article was published in the following Dove Press journal:

Drug Design, Development and Therapy

28 April 20II

Number of times this article has been viewed

\section{Laëtitia Michou \\ Jacques $P$ Brown}

Laval University, Department of Medicine, CHUQ (CHUL) Research Centre and Division of Rheumatology, Quebec City, QC, Canada
Correspondence: Laëtitia Michou Laval University, Department of Medicine, CHUQ (CHUL) Research

Centre and Division of Rheumatology, Room S-763, 2705 Laurier Boulevard, Quebec City, QC, GIV 4G2, Canada $\mathrm{Tel}+\mathrm{I} 4186542178$

$\mathrm{Fax}+\mathrm{I} 4186542142$

Email laetitia.michou@crchul.ulaval.ca
Abstract: Paget's disease of bone (PDB) is a progressive monostotic or polyostotic metabolic bone disease characterized by focal abnormal bone remodeling, with increased bone resorption and excessive, disorganized, new bone formation. PDB rarely occurs before middle age, and it is the second most frequent metabolic bone disorder after osteoporosis, affecting up to $3 \%$ of adults over 55 years of age. One of the most striking and intriguing clinical features is the focal nature of the disorder, in that once the disease is established within a bone, there is only local spread within that bone and no systemic dissemination. Despite many years of intense research, the etiology of PDB has still to be conclusively determined. Based on a detailed review of genetic and viral factors incriminated in PDB, we propose a unifying hypothesis from which we can suggest emerging strategies and therapies. PDB results in weakened bone strength and abnormal bone architecture, leading to pain, deformity or, depending on the bone involved, fracture in the affected bone. The diagnostic assessment includes serum total alkaline phosphatase, total body bone scintigraphy, skull and enlarged view pelvis x-rays, and if needed, additional x-rays. The ideal therapeutic option would eliminate bone pain, normalize serum total alkaline phosphatase with prolonged remission, heal radiographic osteolytic lesions, restore normal lamellar bone, and prevent recurrence and complications. With the development of increasingly potent bisphosphonates, culminating in the introduction of a single intravenous infusion of zoledronic acid $5 \mathrm{mg}$, these goals of treatment are close to being achieved, together with long-term remission in almost all patients. Based on the recent pathophysiological findings, emerging strategies and therapies are reviewed: ie, pulse treatment with zoledronic acid; denosumab, a fully human monoclonal antibody directed against RANK ligand; tocilizumab, an interleukin- 6 receptor inhibitor; odanacatib, a cathepsin $\mathrm{K}$ inhibitor; and proteasome and Dickkopf-1 inhibitors.

Keywords: Paget's disease of bone, bisphosphonates, sequestosome 1, p62, autophagy, pathogenesis, interleukin-6

\section{Introduction}

Paget's disease of bone (PDB) is a progressive monostotic or polyostotic metabolic bone disease characterized by focal abnormal bone remodeling, with increased bone resorption and excessive, disorganized new bone formation. ${ }^{1}$ The disease is driven primarily by increased osteoclast activity, but intrinsic defects in other cell types in the bone microenvironment may contribute to disease onset and severity. ${ }^{2}$ One of the most striking and intriguing clinical features is the focal nature of the disorder, in that once the disease is established within a bone, there is only local spread within that bone and no systemic dissemination. ${ }^{3}$ Further supporting this focal nature, is the clinical observation of PDB transfer from one part of the skeleton to another as 
a result of autologous bone grafting after three years' latency. ${ }^{4}$ While PDB is classically considered to be a focal disease, there is some evidence to suggest that patients have a mild generalized increase in bone turnover as measured by histomorphometry in nonpagetic sites. ${ }^{5}$

PDB affects both men and women, with a slight predominance in men. ${ }^{1}$ PDB rarely occurs before middle age and its prevalence increases steadily with age. It is the second most frequent metabolic bone disorder after osteoporosis, affecting up to $3 \%$ of adults over 55 years of age, ${ }^{6}$ with an unchanged prevalence $(2.5 \%)$ over the last 1000 years, ${ }^{7,8}$ although it appears to be declining over the last 50 years, ${ }^{9}$ which is consistent with a major contribution of environmental triggers for PDB. PDB results in weakened bone strength and abnormal bone architecture, in which the collagen fibers assume a haphazard irregular mosaic pattern (woven bone) instead of the parallel symmetry observed in normal (lamellar) bone. PDB is often asymptomatic, but patients can present with pain, deformity or, depending on the bone involved, fracture in the affected bone. ${ }^{10}$ Approximately 30\%-50\% of PDB patients experience disabilities due to bone pain, osteoarthritis secondary to deformities adjacent to weight-bearing joints, fractures, or nerve root compression. ${ }^{11,12}$ Malignant transformation to osteosarcoma occurs in about $0.3 \%$ of patients. ${ }^{11}$

Despite many years of intense research, the etiology of PDB has still to be conclusively determined. A variety of evidence has implicated members of the Paramyxovirus family as causative agents, ${ }^{13-18}$ UK researchers have previously shown molecular evidence of canine distemper virus in pagetic bone biopsies, ${ }^{15-18}$ whereas groups in the US have predominantly identified measles virus. ${ }^{19,20}$ Although controversial, these data may suggest a slow viral infection in pagetic bone. ${ }^{21,22}$ Further supporting this viral hypothesis are the frequent associations between the development of PDB and contact with domesticated animals or residency in rural areas. ${ }^{23-25}$ The high prevalence of PDB in Lancashire (England) and in New Zealand may be related to both environmental and genetic factors. The declining prevalence and severity of PDB in the British population also suggests that PDB is at least somewhat regulated by environmental factors, ${ }^{26,27}$ although it may be partially due to the influx of migrants from low prevalence regions such as the Indian subcontinent and southeast Asia. ${ }^{28}$ In contrast, the rural region of Campania (Italy) was recently reported to be a high prevalence area for PDB with an increased clinical severity. ${ }^{29,30}$

\section{Diagnosis}

PDB may present with obvious signs or symptoms or it may be an incidental finding during the investigation of other conditions. ${ }^{10}$ In a recent study, PDB appears to be less severe, with $34 \%$ having a monostotic lesion, and an overall average of 5.5 lesions per patient. ${ }^{31}$ The diagnosis of PDB is primarily radiological and confirmed with plain radiology of at least one skeletal site. ${ }^{10}$ The radiological features include initial osteolytic changes (V-shaped lesions in long bones and osteoporosis circumscripta in the skull), followed by sclerotic changes, bone enlargement, and cortical thickening. Plain radiographs are also valuable in the diagnosis of secondary complications of PDB, eg, arthritis or fracture. Total body bone scintigraphy is more sensitive than $\mathrm{x}$-rays and, it is recommended (where available) for patients with asymptomatic PDB and for patients with symptomatic PDB to assess the extent of skeletal involvement. ${ }^{32}$ In contrast with focal assessment of disease by scintigraphy and radiography, biochemical markers of disease activity provide an integrated index, if not of the focal activity of the underlying disorder, then of its extent. ${ }^{33,34}$ Measurement of serum total alkaline phosphatase is still the most frequently used and most useful biochemical marker for clinical management of PDB. ${ }^{35}$ Serum bone alkaline phosphatase and procollagen type $1 \mathrm{~N}$-terminal propeptide, as well as urinary $\mathrm{N}$-terminal telopeptide of type 1 collagen and $\alpha$-C-terminal telopeptide of type 1 collagen have been demonstrated to be similar ${ }^{36}$ or slightly superior ${ }^{37,38}$ to serum total alkaline phosphatase in assessing disease activity and response to therapy in small cohorts of patients. However, monostotic PDB may be associated with levels of serum total alkaline phosphatase within the reference range, introducing difficulties both in diagnosis and follow-up management of patients. ${ }^{39}$ PDB patients with serum total alkaline phosphatase within the reference range may be discriminated from normal controls by an increased bone alkaline phosphatase isoform B2 measured by high-pressure liquid chromatography. ${ }^{40}$ In contrast, serum osteocalcin is not a sensitive marker in PDB, being often in the normal range..$^{41,42}$

In summary, the assessment of PDB includes serum total alkaline phosphatase, total body bone scintigraphy, skull and enlarged view pelvis $\mathrm{x}$-rays (includes pelvis, $1 / 3$ proximal femurs and L3 to L5 vertebrae), and if needed, additional $\mathrm{x}$-rays. This clinical investigation is associated with very high diagnostic sensitivities for PDB, ie, 85\%-91\% for skull and enlarged view pelvis $\mathrm{x}-$ rays $^{43}$ and $97 \%-98 \%$ for bone scintigraphy. ${ }^{44}$ 


\section{Pathogenesis Genetic factors}

Genetic factors play an important role in PDB. ${ }^{45}$ One-third of patients with PDB have a familial form transmitted in an autosomal dominant pattern of inheritance with incomplete penetrance. ${ }^{46-48}$ Genetic heterogeneity has been demonstrated in familial forms of PDB, which have been linked to several chromosomal regions. ${ }^{49} \mathrm{~A}$ linkage between the $6 p 21.3$ locus $(P D B 1)$ and PDB has been suggested, but not confirmed. ${ }^{50}$ Four PDB families were linked to markers in the $18 q 22.1$ locus (PDB2), a locus also involved in familial expansive osteolysis, a rare bone disease caused by a mutation in the tumor necrosis factor receptor superfamily, member $11 \mathrm{a}$, NFKB activator (RANK, TNFRSF11A) gene. ${ }^{51,52}$ However, $R A N K$ gene mutations are not a common cause of classical late-onset $\mathrm{PDB},{ }^{53,54}$ although a genetic association to this gene was recently suggested in PDB patients. ${ }^{55}$ The 5 q35-qter locus $(P D B 3)$ was identified by our research group in a genome-wide scan of three large French-Canadian families, ${ }^{48}$ and replicated in British families. ${ }^{56}$ Taking advantage of the influence of genetic drift and a strong founder effect of the French-Canadian population, we reported in this population the first and still most common germline mutation, $P 392 \mathrm{~L}$, within the SQSTM1 gene, ${ }^{57}$ and this was later confirmed in the British population. ${ }^{58}$ The $5 q 31$ locus (PDB4) was also linked to PDB in two French-Canadian families. ${ }^{48} \mathrm{~A}$ genomewide scan in 62 British families suggested the linkage of PDB with two other loci, 2q36 (PDB5) and 10p13 (PDB6). ${ }^{56}$ Recently, data from this genome-wide scan were reanalyzed and confirmed a linkage to the $10 p 13$ locus, but not to the $2 q 36$ locus. ${ }^{59}$ The $18 q 23$ locus (PDB7) was suggested in an Australian family, ${ }^{60}$ but this locus is more likely to contain a modifier gene rather than a causal gene because a SQSTM1 mutation (L394X) was also found in this pedigree. ${ }^{61}$ Although no linkage of the osteoprotegerin (OPG, TNFRSF11B) locus (8q24) was suggested with PDB, a British study reported a female sex-restricted association of this gene with PDB. ${ }^{62,63}$ Mutations of the valosin-containing protein $(V C P)$ gene, located at $9 p 13-p 12$, were reported in rare families characterized by an autosomal dominant disorder associating PDB with frontotemporal dementia or inclusion body myopathy ${ }^{64}$ However, no mutations were found in pagetic patients in the absence of myopathy or dementia, suggesting that the $V C P$ gene was not a common causal gene of PDB. ${ }^{65}$ Finally, a recently published genome-wide association study in PDB patients, mostly of British descent, identified a significant association between PDB and six common variants, located at the $1 p 13$ (CSF1 gene) and $10 p 13$ (OPTN gene) loci, and, as previously mentioned, at the $18 q 21$ ( $R A N K$ gene) locus. ${ }^{55}$ These genetic associations have been strongly replicated in Belgian and Dutch populations, as well as the association of the dendritic cell-specific transmembrane protein (DC-STAMP, TM7SF4) gene, encoding for a protein involved in cell-cell fusion of osteoclasts. ${ }^{66}$ Among the seven reported loci, the 5q35qter (PDB3) locus is the only one for which a gene has been identified, namely the sequestosome 1 (SQSTM1) gene that encodes the SQSTM1/p62 protein. ${ }^{57}$ More than 20 missense or truncating germline mutations of this gene have now been reported, although the P392L mutation is the most frequent. ${ }^{67,68}$ In the French-Canadian population, the $\mathrm{P} 392 \mathrm{~L}$ recurrent mutation was involved in $46 \%$ of familial forms and $16 \%$ of unrelated cases of PDB. ${ }^{57}$ Sequencing of the SQSTM1 gene in unrelated French PDB patients allowed the identification of two novel mutations, $A 381 \mathrm{~V}$ and $L 413 \mathrm{~F}$, and for the first time, the presence of double mutations of SQSTM1 was reported in PDB ${ }^{69}$ In the American population, 10\% of unrelated PDB patients living in the New York City area carried a SQSTM1 mutation, most frequently the $P 392 L$ mutation, but also the novel $S 349 T$, $A 390 \mathrm{~V}$, and $L 417 Q$ mutations. $^{70}$ Almost all of the SQSTMI mutations are recurrent, and reported in different Caucasian populations on average in $40 \%$ of familial forms of PDB and $8 \%$ of unrelated patients. ${ }^{61,67,69,71}$

\section{NF- $\kappa B$ signaling pathway}

Interestingly, all of the reported SQSTM1 germline mutations result in either missense or truncating mutations ${ }^{67}$ enhancing the NF- $\kappa \mathrm{B}$ signaling pathway. They are clustered either within or near the C-terminal region of the SQSTM1/p62 protein that embodies the ubiquitin-associated domain. This suggests that an alteration of ubiquitin-chain binding by SQSTM1/p62 is important in the development of $\mathrm{PDB},{ }^{72,73}$ resulting in an aberrant RANK-NF- $\mathrm{KB}$ signaling pathway. ${ }^{74}$ In osteoclasts, SQSTM1/p62 has been described as a scaffolding protein that interacts with TRAF6 following activation by the RANK ligand (Figure 1). ${ }^{75}$ Activation of this complex results mainly in the activation of NF- $\kappa B$ and NFATc1 transcription factors. The overexpression of SQSTM1/p62 in osteoclasts from PDB patients induces major shifts in the pathways activated by the RANK ligand and upregulates osteoclast activity. The $P 392 \mathrm{~L}$ mutation may contribute to the overactive state of osteoclasts in $\mathrm{PDB},{ }^{76}$ and could potentially explain the generalized increase in bone turnover observed in nonpagetic bone sites. ${ }^{5}$ 


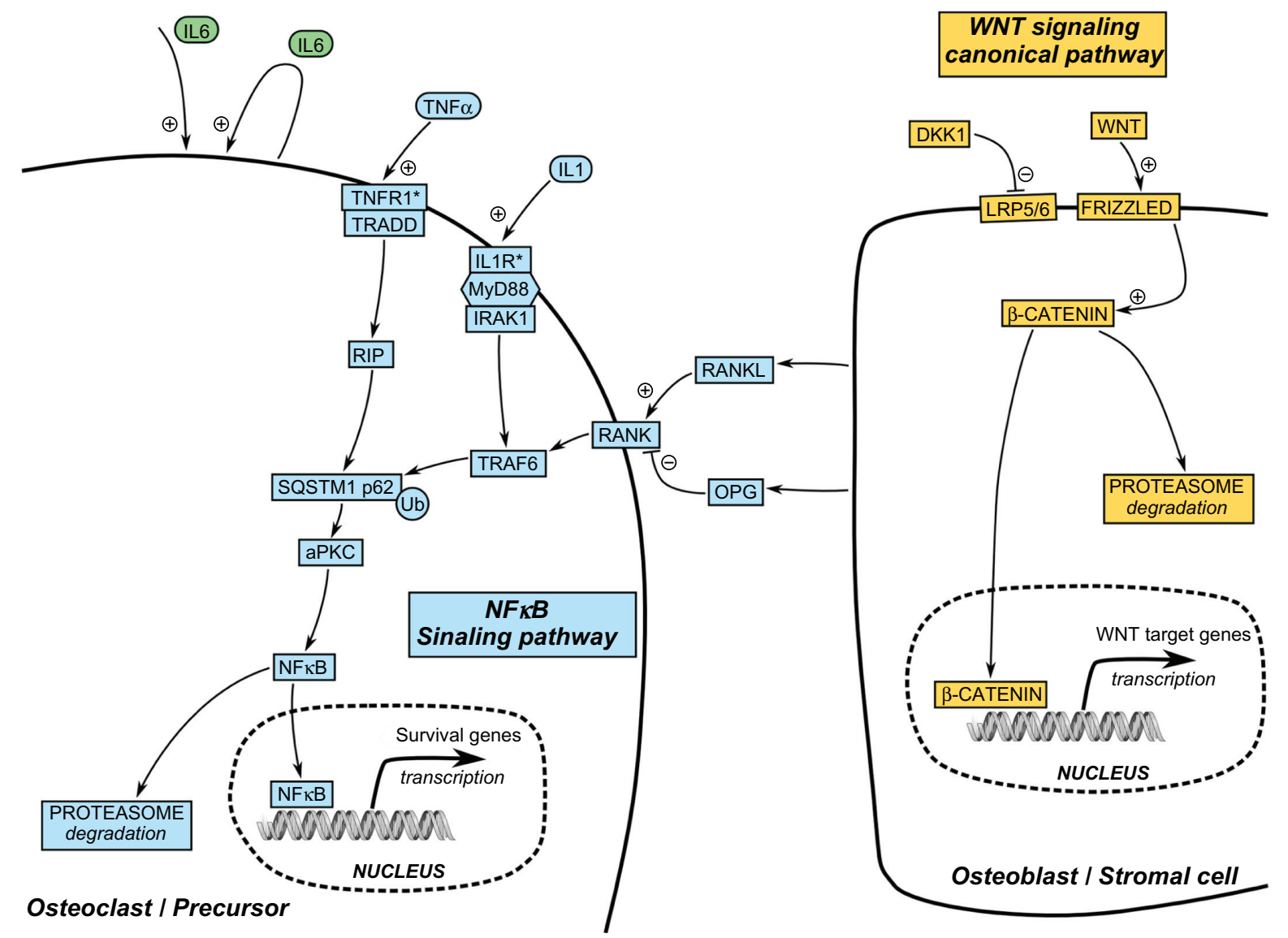

Figure I Most relevant pathways for the identification of potential novel therapeutic targets in Paget's disease of bone.

\section{Ubiquitin-proteasome system, autophagy, and apoptosis}

The ubiquitin-proteasome system is involved in the degradation of short-lived, damaged, or misfolded proteins. Targetto-be-degraded proteins are first tagged with ubiquitin then digested by the proteasome. ${ }^{77,78}$ This system is important for protein degradation and controls various cell functions, including mitosis, signal transduction, gene transcription, immune response, and apoptosis.

Autophagy is another protein degradation system, and includes macroautophagy, microautophagy, and chaperonmediated autophagy. ${ }^{79,80}$ Macroautophagy (hereafter termed autophagy) involves the engulfing of a portion of cytoplasm by a double-membrane structure, the autophagosome. The autophagosome fuses with the lysosome, becoming the autolysosome, which undergoes autodigestion. ${ }^{80,81}$ Autophagy maintains cellular homeostasis and participates in processes including differentiation, remodeling, growth control, cell defense, and adaptation to adverse environments, ${ }^{82}$ and is involved in eliminating abnormal proteins. ${ }^{83}$ Loss of autophagy in mice induces inclusion formation in neurons and hepatocytes. ${ }^{84,85}$
Ubiquitination, through binding of the ubiquitinassociated domain of the p62 protein (encoded by the SQSTM1 gene) to LC3 protein, mediates protein degradation by autophagy and also results in the delivery of p62 itself to autophagosomes for lysosomal degradation. ${ }^{86-88}$ So far, only one PDB-associated germline missense mutation (D335E) has been shown to affect the LC3-binding region. ${ }^{89}$ In PDB, autophagy appears to be defective, with impaired p62 clearance that leads to increased levels of p62 regardless of the SQSTM1 mutation status. ${ }^{69,76}$ p62 not only functions as an adaptor protein that targets substrates to the autophagosome, but also as a scaffold protein interacting with TRAF6 and caspase 8 , promoting polyubiquitination of TRAF6 and activation of NF- $\mathrm{KB}$ signaling, ${ }^{90,91}$ as well as the aggregation of cullin-3 modified caspase 8 , required for apoptosis, within p62-dependent foci ${ }^{92}$ which leads to increases in osteoclast survival. ${ }^{76}$ These increases in osteoclast survival can be induced by artificial overexpression of p62 and appear to be independent of SQSTM1 mutations because they are observed with wild-type and PDB-mutant p62. ${ }^{76}$ Finally, it is interesting to note that osteoclasts from healthy carriers of germline SQSTM1/p62 $2^{\mathrm{P} 392 \mathrm{~L}}$ mutation show an intermediate 
rate of apoptosis between affected individuals and healthy controls. ${ }^{76}$ Exploring the precise nature of the potential link between autophagy and PDB has been judiciously proposed as a priority area because autophagy represents a cellular pathway that can be relatively easily manipulated in vivo by pharmacological agents. ${ }^{93}$

\section{Viral factors}

\section{Canine distemper virus}

Canine distemper virus can infect and replicate in human osteoclast precursors, raising possible zoonotic implications for canine distemper virus. Canine distemper virus transiently induces osteoclastogenesis in human osteoclast precursor cultures via NF- $\kappa \mathrm{B}$ and SQSTM1/p62 activation. ${ }^{94} \mathrm{~A}$ variety of other proteins have been shown to be upregulated in PDB, notably Bcl-2, ${ }^{95}$ leading to an enhanced lifespan of pagetic osteoclasts. Hence, it is possible that the viral effects on ubiquitin and SQSTM1/p62 are only transient, but that the effects on other proteins, such as Bcl-2, lead to an enhanced lifespan of the enlarged osteoclast, with the subsequent recruitment of further precursor cells, thus increasing the size and bone resorbing capacity further.

\section{Measles virus nucleocapsid protein}

Osteoclasts in PDB are increased in number and size and express a "pagetic phenotype" that distinguishes them from normal osteoclasts. They contain up to 100 nuclei/osteoclast compared with 3-10 nuclei in normal osteoclasts, their precursors are hyperresponsive to the RANK ligand, tumor necrosis factor alpha, and $1,25(\mathrm{OH})_{2}$ vitamin $\mathrm{D}_{3}{ }^{96-98}$ and form osteoclast at physiologic concentrations of $1,25(\mathrm{OH})_{2}$ vitamin $\mathrm{D}_{3}\left(10^{-11} \mathrm{M}\right)$ rather than the pharmacologic $1,25(\mathrm{OH})_{2}$ vitamin $\mathrm{D}_{3}$ concentrations $\left(10^{-8} \mathrm{M}\right)$ required for normal osteoclast formation. The $1,25(\mathrm{OH})_{2}$ vitamin $\mathrm{D}_{3}$ hyperresponsivity results from elevated levels of a novel vitamin D receptor coactivator, TAF12 (formerly TAF $_{\mathrm{II}}-17$ ) in osteoclasts. ${ }^{97}$ Furthermore, osteoclasts in PDB secrete high levels of interleukin (IL)-6, which are detectable in marrow plasma and peripheral blood from patients with Paget's disease. ${ }^{99}$

Both measles virus nucleocapsid (MVNP) and the SQSTM1/p62 ${ }^{\mathrm{P} 392 \mathrm{~L}}$ mutation have been implicated in the pathogenesis of PDB, but their relative contributions are not yet clearly defined. We recently reported that osteoclast from approximately $70 \%$ of PDB patients express MVNP, and that normal osteoclast precursors expressing MVNP formed osteoclasts that express the "pagetic phenotype". ${ }^{100,101}$ Furthermore, $30 \%$ of transgenic mice with targeted expression of MVNP to osteoclasts developed osteoclast and bone lesions characteristic of PDB. ${ }^{102}$

At least 21 genetic mutations of the SQSTM1/p62 gene are linked to $\mathrm{PDB}$, with $\mathrm{p} 62^{\mathrm{P} 392 \mathrm{~L}}$ mutation being the most frequent. ${ }^{57,67,103}$ However, the role of p62 $2^{\mathrm{P} 392 \mathrm{~L}}$ in $\mathrm{PDB}$ is unclear because normal osteoclast precursors expressing $\mathrm{p} 62^{\mathrm{P} 392 \mathrm{~L}}$ are hyperresponsive to the RANK ligand but not to $1,25(\mathrm{OH})_{2} \mathrm{D}_{3}$, do not express high levels of IL-6 or TAF12, or form bone lesions or osteoclasts characteristic of PDB. ${ }^{104,105}$

Therefore, to assess the roles of MVNP and $\mathrm{p} 62^{\mathrm{P} 392 \mathrm{~L}}$ in $\mathrm{PDB}$, marrow from clinically involved and uninvolved bones of PDB patients with $\mathrm{p} 62^{\mathrm{P} 392 \mathrm{~L}}$ and normals was tested for MVNP, and the effects of antisense MVNP on the osteoclast formed were determined. ${ }^{101}$ To delineate the mechanism(s) responsible for the abnormal osteoclast activity and bone formation seen with coexpression of MVNP and p62 $2^{\mathrm{P} 392 \mathrm{~L}}$, p62 ${ }^{\mathrm{P} 394 \mathrm{~L}}$ knockin mice (the mouse equivalent of $\mathrm{p} 62^{\mathrm{P} 392 \mathrm{~L}}$ ) were bred to transgenic mice expressing MVNP in osteoclasts producing the $\mathrm{p} 62^{\mathrm{P} 394 \mathrm{~L}}$ knockin/MVNP mice. These mice developed more pagetic osteoclast and pagetic bone lesions than transgenic mice expressing MVNP in osteoclasts. ${ }^{101}$ The p62 $2^{\mathrm{P} 392 \mathrm{~L}}$ gene increased RANK ligand sensitivity of osteoclast precursors while MVNP was responsible for osteoclast hypermultinucleation, increased TAF-12 expression, and IL-6 production through enhanced p38MAPK signaling induced by $1,25(\mathrm{OH})_{2} \mathrm{D}_{3} \cdot{ }^{101}$ Furthermore, when transgenic mice expressing MVNP in osteoclasts were bred to IL-6 knockout mice, pagetic osteoclast formation no longer occurred. ${ }^{101}$

In conclusion, studies in mice have demonstrated that the p $62^{\mathrm{P} 392 \mathrm{~L}}$ mutation leads to some of the phenotypic characteristics of PDB, but this single mutation is seemingly unable to result in the whole PDB phenotype. This mutation may predispose to PDB by increasing the sensitivity of osteoclastic precursors to osteoclastogenic cytokines ${ }^{104}$ and/or the osteoclastogenic potential of the bone microenvironment, ${ }^{105}$ probably in association with other biological mechanisms, such as the presence of MVNP, which is responsible for osteoclast hypermultinucleation, increased TAF-12 expression, and IL-6 production. ${ }^{101,106}$

\section{SQSTMI/p62, selective autophagy, and measles virus persistence}

A unifying hypothesis for SQSTM1/p62, selective autophagy, and measles virus persistence is shown in Figure 2. It has been recently suggested that successful clearance of viral proteins through p62-mediated selective autophagy may 


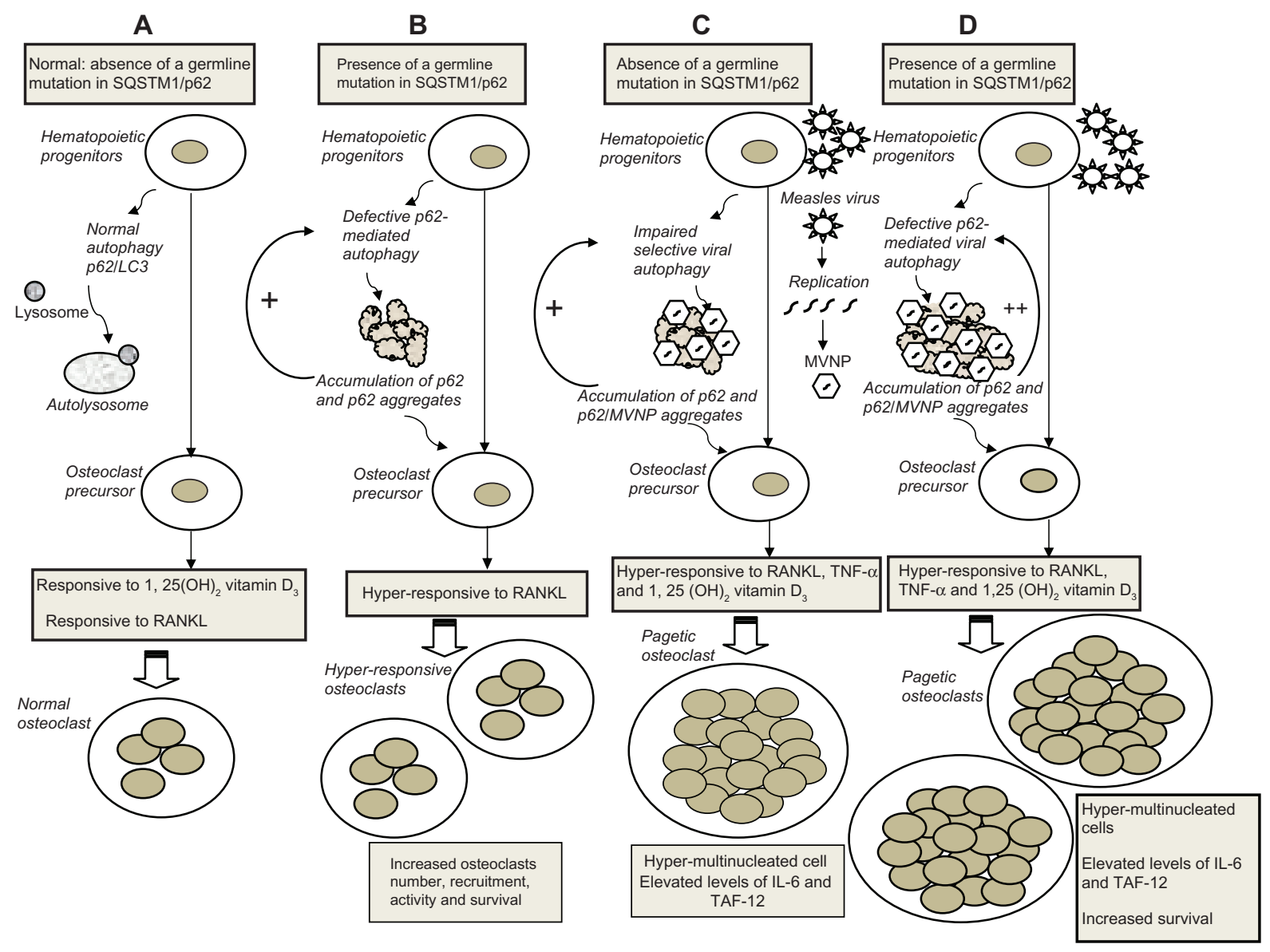

Figure 2 Pathogenesis of Paget's disease of bone: Viral and genetic interactions, unifying hypothesis. Schematic models of cytoplasmic autophagy in A) normal hematopoietic progenitors with adequate clearance of the autolysosome by the proteasome, B) hematopoietic progenitors carrying a germline SQSTMI/P62 mutation leading to defective p62-mediated autophagy, accumulation of p62, further amplifying the process, and p62 aggregates, C) hematopoietic progenitors with persistent measles virus infection and replication leading to impaired autophagy with accumulation of MVNP/p62 aggregates, $\mathbf{D}$ ) persistent measles virus infection of hematopoietic progenitors carrying a germline SQSTMI/p62 mutation further amplifies the genetically-induced defective p62-mediated autophagy. B-D) These abnormalities in the autophagy process are perpetuated in cells differentiated from the hematopoietic cells with specific functional consequences on mature osteoclasts (see text).

represent an integral component of the normal host antiviral defense response. ${ }^{79}$ Virus-induced autophagy usually requires viral replication ${ }^{80}$ and is then followed by viral persistence. The measles virus is a monotypic virus existing as a single serotype and is among the most infectious viruses. ${ }^{89}$ Measles virus infections predominantly occur in children, and infection or vaccination with any one strain appears to provide life-long protection from the disease. ${ }^{89}$ It would be difficult to accept life-long persistence of measles virus RNA or protein in the absence of viral replication and low level gene expression.$^{86}$ Indeed, intracellular nonreplicating MVNP are inactivated within three days ${ }^{88}$ Osteoclasts have a short lifespan (2-3 weeks) and are not self-renewing cells, but are rather formed by fusion of postmitotic precursors of the monocyte-macrophage lineage..$^{90}$ Immature multipotential hematopoietic progenitors that give rise to granulocytes, erythrocytes, macrophages, and platelets, also express MVNP transcripts, while nonhematopoietic stromal cells do not. ${ }^{87}$
These cells could easily be the reservoir for measles virus persistence in PDB, although direct evidence is lacking. Toll-like receptors 2 and 4 have been shown to increase susceptibility to measles virus infection, ${ }^{91}$ suggesting a predisposing role of innate immunity.

We can then speculate that measles virus persistence could explain the latency between measles virus infection in childhood and PDB development in middle age. ${ }^{86}$ Measles virus persistence would also explain the presence of MVNP in lifelong immature multipotential hematopoietic progenitors, ${ }^{87}$ later differentiating into osteoclasts, and would be responsible for osteoclast hypermultinucleation, increased TAF-12 expression, $1,25(\mathrm{OH})_{2}$ vitamin $\mathrm{D}_{3}$ responsivity, and IL-6 production. ${ }^{101,106}$ Defective p62-mediated selective autophagy of MVNP, by germline SQSTM1/p62 mutation or other causes, would lead to accumulation of p62 itself as well as MVNP-p62 aggregates in osteoclasts and antigenpresenting cells, reducing their clearance by the proteasome. ${ }^{79}$ 
Mutant $\mathrm{p} 62^{\mathrm{P} 392 \mathrm{~L}}{ }^{76}$ or any other SQSTM1/p62 mutations associated with PDB and overexpression of native $\mathrm{p} 62$, are increasing osteoclast responsiveness to RANK ligand f $^{76,104,105}$ and osteoclast survival, ${ }^{76}$ which translates clinically into a more severe phenotypic expression of the disease. ${ }^{67}$

\section{Treatment}

\section{Indications for therapy}

Guidelines on clinical management of PDB have been published by expert committees from various countries..$^{10,32,107-109}$ Pain in pagetic bone is the only symptom of PDB for which there is firm evidence that therapy confers a clinical benefit, ${ }^{110}$ and is, therefore, a definite indication for antipagetic therapy. It is important to distinguish bone pain that occurs as a result of pagetic activity (ie, pain in pagetic bone) from pain in a bone and/or joint deformity that occurs as a consequence of the disease (ie, osteoarthritic pain). The former is usually present at rest, whereas the latter occurs during mobilization of the joint and can, therefore, respond to analgesics, but not to antipagetic drugs.

Pharmacological treatment to prevent future complications, such as osteoarthritis, fracture, hearing loss, or other neurological complications, is more controversial. ${ }^{111}$ In a 12-year study of 41 patients with PDB, osteoarthritic complications occurred in $62 \%$ of patients, in whom serum total alkaline phosphatase levels were halved after therapy compared with $33 \%$ of those who had normal serum total alkaline phosphatase following treatment. ${ }^{112}$ Therefore, a reasonable strategy is to treat pain even when its cause is unclear, because it can often be difficult to distinguish between PDB pain and osteoarthritic pain. ${ }^{10}$ Both symptomatic and asymptomatic patients with metabolically active PDB requiring therapy include those with involvement of long bones at risk of future bowing deformities, those with extensive skull involvement at risk for future hearing loss, those with pagetic changes in one or more vertebrae with the risk of various neurological complications, and those with PDB in bones adjacent to major joints with the risk of secondary arthritis. ${ }^{32,107}$ Because current therapies improve radiographic osteolytic lesions ${ }^{113}$ and allow normal lamellar bone deposition, ${ }^{114}$ it is likely that associated complications could be prevented if treatment is administered at an early stage. ${ }^{11,112,115} \mathrm{~A}$ recent three-year prospective study known as PRISM (Paget's Disease: a Randomized Trial of Intensive Versus Symptomatic Management) ${ }^{116}$ in 1324 patients with long established PDB, concluded that intensive bisphosphonate therapy has no beneficial effect on quality of life, bone pain, or clinical complications (fracture and osteoarthritis) compared with symptomatic management. The negative findings from the PRISM trial could be explained by numerous limitations in the trial design. ${ }^{115,117}$ Unevenly potent treatment was given late in the disease process, the primary endpoint was inadequate (ideally pain or alternatively fracture in pagetic bone should have been used rather than clinical fracture at any site), and the sample size was too small and the observational period too short to impact on the clinical management of PDB. For preventing complications associated with $\mathrm{PDB}$, initiating pharmacological therapy at the right time (at an early disease stage) is clearly more important than using a highly potent bisphosphonate.

\section{Contraindications to therapy}

Elderly asymptomatic patients whose life span would likely limit the chance of future complications ${ }^{111}$ and those with metabolically inactive pagetic lesions (no radiographic osteolytic lesions nor increased uptake on bone scintigraphy) are not candidates for pharmacological therapy. Patients with vitamin D deficiency should be repleted before therapy is initiated to prevent severe hypocalcemia. ${ }^{118}$

\section{Goals of therapy}

Physicians treating PDB should aim for a complete remission, as defined by normalization of serum total alkaline phosphatase and even a nadir value in the lower half of the reference range. ${ }^{119}$ The ideal therapeutic option would eliminate bone pain, normalize serum total alkaline phosphatase with prolonged remission, heal radiographic osteolytic lesions, restore normal lamellar bone, and prevent recurrence and complications. $^{32}$

\section{Current pharmacological therapies}

The first effective therapy was salmon calcitonin, available in the 1970s as daily subcutaneous formulations, followed by human calcitonin. Calcitonin acts directly on calcitonin receptors expressed on osteoclasts. ${ }^{120}$ Because calcitonin was associated with partial response, acquired resistance, and a short-lived action, it is not used clinically any more.

Bisphosphonates are a class of drugs related to the naturally occurring mineralization inhibitor, inorganic pyrophosphate. ${ }^{121}$ In biological systems, they are able to bind to the surface of hydroxyapatite crystals within bone, especially on those surfaces undergoing active osteoclastic resorption. Bisphosphonates work according to one of two main mechanisms of action, depending on the chemical nature of the side chain attached to the basic bisphosphonate core. The relatively weak, non-nitrogen, simple bisphosphonates 
(ie, etidronate, clodronate, and tiludronate) inhibit bone resorption by generating a toxic analog of adenosine triphosphate, which then targets the mitochondria. ${ }^{122}$ For the more potent, nitrogen-containing bisphosphonates (ie, alendronate, ibandronate, pamidronate, risedronate, and zoledronic acid), the direct intracellular target in osteoclasts is the farnesyl pyrophosphate synthase enzyme in the mevalonate pathway. ${ }^{122}$ Its inhibition suppresses a process called protein prenylation, which is essential for the basic cellular processes required for osteoclastic bone resorption and cell survival.

Nitrogen-containing bisphosphonates are the treatment of choice for PDB. The advent of ever more powerful bisphosphonates has led to an aim for a more stringent definition of biochemical response to therapy, ie, a reduction of serum total alkaline phosphatase into the normal range and even a nadir value in the lower half of the reference range. ${ }^{119}$

Comparative trials have been published evaluating the relative efficacy of the bisphosphonates in the treatment of PDB. These trials typically use extent of suppression of serum total alkaline phosphatase and duration of remission as evidence of superior treatment. Table 1 provides a summary of the clinical trials assessing the efficacy of bisphosphonates in PDB, as measured by the proportion of patients achieving normalization of serum total alkaline phosphatase. ${ }^{42,123-128}$ This table reports the results from independent studies without any attempt to compare efficacy between therapies that have not been compared in a head-to-head trial. Although of somewhat differing protocols, these trials demonstrate that alendronate and risedronate are superior to etidronate. In a small comparative study of previously untreated patients, oral alendronate $(40 \mathrm{mg} /$ day in three-month blocks) and intravenous pamidronate (60 mg every three months) were given until normalization of serum total alkaline phosphatase, which was observed at one year in $86 \%$ and $56 \%$ of patients, respectively. ${ }^{129}$ In previously treated patients,

Table I Summary of clinical trials assessing bisphosphonate efficacy in Paget's disease of bone as measured by the proportion of patients with normalization of serum total alkaline phosphatase

\begin{tabular}{llll}
\hline Drug name & Regimen & Duration & $\%$ n sTALP \\
\hline Etidronate $^{123}$ & $400 \mathrm{mg} /$ day, oral & 6 months & 15 \\
*Clodronate $^{124}$ & $1600 \mathrm{mg} /$ day, oral & 6 months & 60 \\
*Tiludronate $^{125}$ & $400 \mathrm{mg} /$ day, oral & 3 months & 39 \\
*Pamidronate $^{126}$ & $60 \mathrm{mg} /$ day, IV & 3 days & 53 \\
*Alendronate $^{127}$ & $40 \mathrm{mg} /$ day, oral & 6 months & 63 \\
Risedronate $^{123}$ & $30 \mathrm{mg} /$ day, oral & 2 months & 73 \\
*lbandronate $^{42}$ & $6 \mathrm{mg} /$ day, IV & 2 days & 70 \\
Zoledronic acid $^{128}$ & $5 \mathrm{mg}$, IV & One dose & 89 \\
\hline
\end{tabular}

Note: *Small sample size.

Abbreviations: sTALP, serum total alkaline phosphatase; IV, intravenously. alendronate resulted in normalization of serum total alkaline phosphatase in $79 \%$ compared with $14 \%$ for pamidronate. ${ }^{129}$ At one year, nonresponders to pamidronate were crossed over to alendronate treatment, and $71 \%$ achieved normalization of serum total alkaline phosphatase. ${ }^{129}$ In another comparative trial, normalization of serum total alkaline phosphatase was achieved at six months in $93 \%$ of patients treated with intravenous zoledronic acid $4 \mathrm{mg}$ and in $35 \%$ of patients treated with intravenous pamidronate $60 \mathrm{mg}$ every three months. ${ }^{130}$ At six months, nonresponders to pamidronate were treated with intravenous zoledronic acid $4 \mathrm{mg}$ or intravenous neridronate $100 \mathrm{mg}$, and normalization of serum total alkaline phosphatase was achieved in more than $90 \%{ }^{130}$ A once-weekly alendronate $280 \mathrm{mg}$ oral buffered solution was recently compared with an alendronate $40 \mathrm{mg} /$ day tablet. While both were similarly effective (percentage of patients with serum total alkaline phosphatase normalization not provided), the $40 \mathrm{mg}$ daily tablet was better tolerated. ${ }^{131}$ Recent comparison of intravenous zoledronic acid $5 \mathrm{mg}$ and oral risedronate $30 \mathrm{mg}$ daily for 60 days in 357 patients after six months showed normalization of serum total alkaline phosphatase in $89 \%$ of zoledronic acid-treated patients and $58 \%$ of risedronate-treated patients. ${ }^{128}$

In the zoledronic acid group, mean scores for each of the eight components of the SF-36 trended upward at both three and six months, suggesting improvements in quality of life, whereas the responses were more mixed in the risedronate group. ${ }^{128}$ Patients in remission at six months were followed for duration of response and, after two years, ${ }^{132}$ zoledronic acid $5 \mathrm{mg}$ extended remission in $98 \%$ of patients with one single dose, compared with $57 \%$ with risedronate, and at 5-6 years these figures were $87 \%$ and $38 \%$, respectively. ${ }^{133}$ Acquired resistance has been commonly observed with etidronate and pamidronate, but not with alendronate, risedronate, or zoledronic acid. ${ }^{134}$ Upper gastrointestinal intolerance and abdominal pain have been reported as the most frequent adverse events associated with oral bisphosphonates. ${ }^{135}$ Postinfusion syndrome (a flu-like illness) occurs in about $15 \%$ of patients treated with intravenous bisphosphonates (pamidronate, ibandronate, and zoledronic acid), and this almost exclusively at the first infusion. ${ }^{119,128}$ Oral bisphosphonates should not be used in patients with esophageal stricture or dysmotility. All bisphosphonates should be avoided in patients with renal insufficiency and severe vitamin D deficiency. Osteonecrosis of the jaw and subtrochanteric fractures are very rare events and their pathophysiology remains unclear. ${ }^{135}$ However, overall, only a very small proportion of patients treated with 
bisphosphonates experience adverse events and the overall benefits have consistently outweighed their potential risks.

\section{Monitoring and retreatment}

Serum total alkaline phosphatase is the most commonly used method of monitoring disease activity. ${ }^{10}$ It should be measured every three months for the first six months after therapy and every six months thereafter. ${ }^{10}$ Pretherapeutic serum total alkaline phosphatase is often within the normal range in monostotic disease, and it cannot be used for monitoring. ${ }^{136}$ Bone scintigraphy (normal uptake) or plain radiographs (filling of osteolytic lesions ${ }^{113}$ ) performed six months after treatment would constitute the ideal monitoring. Retreatment is usually indicated when there are persistent symptoms of PDB or biochemical relapse. ${ }^{10}$ Although there is no clinical trial evidence to guide clinicians, it is generally accepted that an increase of $25 \%$ above nadir indicates significant relapse requiring retreatment. ${ }^{10}$

\section{Mechanisms of action of bisphosphonates in PDB}

Recent in vitro studies suggest that pulse treatment with zoledronic acid, achieving micromolar concentrations (rather than the nanomolar concentrations usually observed in clinical use) similar to what is observed with a single intravenous infusion of $5 \mathrm{mg}$, causes inhibition of proliferation and induction of apoptosis in human mesenchymal stem cells and enhances differentiation through the osteoblastic lineage. ${ }^{137}$ Emerging preclinical and clinical evidence suggests that, in addition to their selected inhibition of osteoclastic activity, bisphosphonates exert anticancer activity by interacting with monocytes, macrophages, and tumor cells, and by stimulating the expansion of $\gamma \delta \mathrm{T}$ cells, a subset of human T cells with antitumor activity. ${ }^{138}$ Focal high bone turnover lesions like PDB or bone metastases do enrich bisphosphonates in the surrounding bone. Only under those circumstances may it be envisaged that bisphosphonate concentrations in the microenvironment exceed micromolar concentrations for a longer period of time and thus propagate apoptosis of pluripotential hematopoietic progenitors, leading to the longterm remissions observed in PDB after a single intravenous zoledronic acid infusion. ${ }^{133}$

\section{Potential therapeutic targets}

Although bisphosphonates are currently the treatment of choice for the management of PDB, uncertainty about the long-term health consequences of these drugs may now lead to consideration of potential alternative therapies, particularly targeted therapies already designed and used, or about to be used, in clinical practice for the management of other bone disorders.

\section{RANK ligand inhibition}

RANK ligand inhibition by the use of a fully human monoclonal antibody (denosumab) induces, in clinical trials, a profound but reversible inhibition of bone resorption. This targeted therapy may be considered for the treatment of OPG/RANK/RANK ligand pathway-mediated diseases, mainly postmenopausal osteoporosis, bone erosion in inflammatory arthritis, and cancer-induced bone disease. ${ }^{139}$ In PDB, the OPG/RANK/RANK ligand system is usually normal, although enhanced RANK ligand expression and responsivity in bone marrow cells have been reported. ${ }^{98}$ Moreover, the pathophysiology of several PDB-related diseases involves the OPG/RANK/RANK ligand system, such as mutation in the signal peptide region of the $R A N K$ gene in familial expansile osteolysis and a mutation in the $O P G$ gene in juvenile Paget's disease. ${ }^{140}$

\section{Interleukin-6 inhibition}

Almost 20 years ago, osteotropic factors, such as $1,25(\mathrm{OH})_{2}$ vitamin $\mathrm{D}_{3}$, parathyroid hormone, and IL-1, were shown to stimulate osteoblast release of IL-6 which, at low concentrations $(<10 \mathrm{ng} / \mathrm{mL})$, stimulates osteoclast formation from precursors, and at higher concentrations, stimulates mature osteoclasts to resorb bone. ${ }^{141}$ IL-6 plays a central role in the development of the abnormal phenotype of osteoclast in PDB, mainly in the multinucleation and hypersensitivity to $1,25(\mathrm{OH})_{2}$ vitamin D3. ${ }^{90} \mathrm{IL}-6$ was found to be overexpressed in pagetic osteoblasts, and may be involved in both stimulation of osteoclast proliferation and inhibition of osteoblast growth. ${ }^{2}$ However, a recent study did not find any association of common polymorphisms in IL-6, IL-8, and tumor necrosis factor alpha genes with PDB. ${ }^{142}$ Tocilizumab, an IL-6 receptor inhibitor, has recently been approved for the treatment of rheumatoid arthritis. ${ }^{143}$ Although IL-6 plays a key role in causing joint damage in rheumatoid arthritis through possible indirect effects on osteoclastogenesis and bone resorption, ${ }^{144}$ no clinical trials have been initiated to date in metabolic bone disorders associated with high levels of IL-6.

\section{Dickkopf-I inhibition}

Dickkopf-1 is a natural secreted antagonist of the Wnt/ $\beta$-catenin signaling interacting with the LRP5/6 coreceptor (Figure 1). Surprisingly, Dickkopf-1 RNA and protein levels are increased in pagetic osteoblast and stromal cells, ${ }^{2}$ 
giving new insights into the role of the osteoblast in PDB. A later independent study reported increased circulating Dickkopf-1 levels in serum from PDB patients, ${ }^{145}$ and suggested Dickkopf-1 as a potential therapeutic target in PDB. ${ }^{146}$ Indeed, high levels of Dickkopf-1 have also been reported in multiple myeloma, osteosarcoma, and rheumatoid arthritis, and Dickkopf-1 targeted therapy gave preliminary promising results in multiple myeloma and rheumatoid arthritis. ${ }^{146}$

\section{Strategies for novel therapeutic target identification}

Relevant strategies for the identification of novel therapeutic targets in PDB may rely mostly on the investigation of novel targets developed for the management of other bone disorders and of the results from genetic studies.

\section{Investigation of novels targets developed in other bone disorders}

Several metabolic disorders share common pathophysiological features with PDB, such as multiple myeloma, osteoporosis, rheumatoid arthritis-induced bone erosions, and bone metastases of cancer with high affinity for bone, such as prostate and breast cancers. In both PDB and bone metastases, increased osteoclast formation and the increased osteoclastogenic nature of the bone microenvironment are mediated by common factors, namely IL-6 and RANK ligand. ${ }^{147}$ Available data suggest that, in the case of PDB, there is increased RANK ligand and IL-6 production, and IL-6 enhances responsivity of the osteoclast precursors to RANK ligand, contributing to the elevated numbers of osteoclasts. In patients with multiple myeloma, $95 \%-100 \%$ of whom develop osteolytic bone lesions, both IL-6 and RANK ligand levels are increased. ${ }^{147}$ We will mainly focus the remaining discussion on therapeutic targets for multiple myeloma and osteoporosis

Bone destruction in multiple myeloma is associated with increased osteoclast formation and activity like in PDB, but with decreased or absent osteoblast differentiation and activity. ${ }^{148}$ The impairment of osteoblast activity in multiple myeloma results primarily from blockade of osteogenic differentiation of mesenchymal progenitors into mature osteoblasts. Multiple myeloma patients have low to normal levels of bone formation markers, such as alkaline phosphatase and osteocalcin, in the setting of increased bone resorption. In contrast, multiple myeloma patients without bone lesions display balanced bone remodeling with increased osteoclastogenesis and normal or increased bone formation rates. Both soluble factors and cell-to-cell contact between multiple myeloma cells and osteoblast progenitors are responsible for the suppression of osteoblast differentiation in multiple myeloma. Current approaches for the development of target-specific treatment in multiple myeloma concern mainly second-generation proteasome inhibitors, new immunomodulating drugs or thalidomide derivatives, histone deacetylase, and heat shock protein 90 inhibitors. ${ }^{149-151}$

Other potential targets are represented by inhibitors of Akt and of PI3K/Akt signaling (rapamycin inhibitors), Bcl2 inhibitors and other promoters of apoptotic pathways, MAPK and telomerase inhibitors, to name a few. ${ }^{151}$ Antibodies have also been designed in multiple myeloma to inhibit IL-6, CD56 (neuronal cell adhesion molecule), CD138 (syndecan-1, a receptor for endothelial growth factor ligands) and Cs1, a cell surface glycoprotein. ${ }^{151}$ In addition to bisphosphonates, novel therapies are considered for the treatment of bone disease in multiple myeloma, such as denosumab, which specifically inhibits RANK ligand-RANK interaction, bortezomib which is a proteasome antagonist inducing myeloma cell apoptosis, and immunomodulating drugs, which inhibit osteoclast activity by decreasing the expression of cathepsin K. ${ }^{152}$ Other inhibitors targeting natural antagonists of Wnt signaling, such as Dickkopf-1 and secreted frizzled-related proteins, have been targeted, as well as inhibitors of IL-3 and Il-7. ${ }^{152}$

Osteoporosis is characterized by a generalized increase in bone resorption, whereas PDB has both focal excesses of bone resorption and many unaffected bones that preserve normal bone remodeling. Both antiresorptive and anabolic agents have being designed as potential novel therapies in osteoporosis. In addition to denosumab, another antiresorptive agent called odanacatib, which is an inhibitor of cathepsin $\mathrm{K}$, is currently being investigated in osteoporosis, as well as glucagon-like peptide 2, an intestinal hormone which may act as an antiresorptive agent with no reduction in bone formation. ${ }^{153}$ Novel anabolic agents targeting the Wnt signaling pathway designed for future osteoporosis management should be considered with caution, and may probably be contraindicated in PDB, considering the increased risk of osteosarcoma in this disorder.

\section{Results of genetic studies}

Gene expression profiling in RNA extracted from various cell types in pagetic patients has revealed that a huge number of genes may be significantly upregulated or downregulated in PDB, providing novel insights for potential future targeted therapies (Table 2)., ${ }^{2,154,155}$ Considering difficulties of performing large-scale proteomic studies in bone cells, 
Table 2 Genes which showed statistically significant differential gene expression in various cell types from patients affected by Paget's disease of bone

\begin{tabular}{|c|c|c|c|}
\hline Gene symbol & Encoded protein & Human cell type & Reference \\
\hline \multicolumn{4}{|c|}{ Downregulated genes } \\
\hline ACP5 & Acid phosphatase 5 , tartrate resistant & Osteoclast* & 154 \\
\hline CASP3 & Caspase 3 , apoptosis-related cysteine peptidase & Osteoclast* & 154 \\
\hline CTSK & Cathepsin K & Osteoclast* & 154 \\
\hline FLJ23191 & Chromosome 4 open reading frame 31 & Osteoblast & 2 \\
\hline GCA & Grancalcin, EF-hand calcium binding protein & Osteoblast & 2 \\
\hline GLRB & Glycine receptor, beta & Osteoblast & 2 \\
\hline MAFB & $\begin{array}{l}\text { V-maf musculoaponeurotic fibrosarcoma } \\
\text { oncogene homolog B (avian) }\end{array}$ & Osteoblast & 2 \\
\hline MAPT & Microtubule-associated protein tau & Osteoclast* & 154 \\
\hline SATB2 & SATB homeobox 2 & Osteoblast & 2 \\
\hline$T N F \alpha$ & Tumor necrosis factor & $\begin{array}{l}\text { Monocytes } \\
\text { Lymphocytes }\end{array}$ & 155 \\
\hline TNFRSFIOA & $\begin{array}{l}\text { Tumor necrosis factor receptor superfamily, } \\
\text { member } 10 \mathrm{a}\end{array}$ & Osteoclast* & 154 \\
\hline TNFRSFI IA & $\begin{array}{l}\text { Tumor necrosis factor receptor superfamily, } \\
\text { member I Ia, NFKB activator }\end{array}$ & Osteoclast* & 154 \\
\hline \multicolumn{4}{|c|}{ Upregulated genes } \\
\hline EPB4IL4B & Erythrocyte membrane protein band 4.I like 4B & Osteoblast & 2 \\
\hline GULPI & GULP, engulfment adaptor PTB domain containing I & Osteoblast & 2 \\
\hline IFN $\alpha$ & Interferon, alpha I & $\begin{array}{l}\text { Monocytes } \\
\text { Lymphocytes }\end{array}$ & 155 \\
\hline IFN $\beta$ & Interferon, beta I, fibroblast & $\begin{array}{l}\text { Monocytes } \\
\text { Lymphocytes }\end{array}$ & 155 \\
\hline IFN $\gamma$ & Interferon, gamma & $\begin{array}{l}\text { Monocytes } \\
\text { Lymphocytes }\end{array}$ & 155 \\
\hline$I F N \gamma R I$ & Interferon gamma receptor I & $\begin{array}{l}\text { Monocytes } \\
\text { Lymphocytes }\end{array}$ & 155 \\
\hline IFN $\gamma R$ R2 & $\begin{array}{l}\text { Interferon gamma receptor } 2 \\
\text { (interferon gamma transducer I) }\end{array}$ & $\begin{array}{l}\text { Monocytes } \\
\text { Lymphocytes }\end{array}$ & 155 \\
\hline KRTI8 & Keratin 18 & Osteoblast & 2 \\
\hline P38 $\beta 2$ MAPK & Mitogen-activated protein kinase 14 & Monocytes & 155 \\
\hline RAI3 & $\begin{array}{l}\text { G protein-coupled receptor, family } \mathrm{C} \text {, } \\
\text { group } 5 \text {, member } \mathrm{A}\end{array}$ & Osteoblast & 2 \\
\hline RBPMS & RNA binding protein with multiple splicing & Osteoblast & 2 \\
\hline STATI & Signal transducer and activator of transcription I, 91 kDa & Monocytes & 155 \\
\hline STAT2 & Signal transducer and activator of transcription $2,113 \mathrm{kDa}$ & Lymphocytes & 155 \\
\hline$T N X B$ & Tenascin XB & Osteoblast & 2 \\
\hline
\end{tabular}

Note: *Peripheral blood monocytes differentiated in vitro into mature osteoclasts.

genome-wide analyses, such as the genome-wide association study recently published in $\mathrm{PDB},{ }^{55}$ or genome-wide investigations of copy number alterations or epigenetic modifications, may be considered as innovative and promising ways to identify novel targets or novel pathways for potential future therapies in PDB. Indeed, the recently published genome-wide association study reported a strong genetic association with three common polymorphisms located upstream of the CSF1 gene. ${ }^{55} \mathrm{CSF} 1$ gene encodes macrophage colony-stimulating factor, which is a key cytokine secreted by bone marrow stromal cells and osteoblasts, which induces the expression of RANK in osteoclast precursors, further inducing osteoclast differentiation and osteoclast activity and survival regulation. ${ }^{156}$ Serum levels of macrophage colony-stimulating factor were reported to be significantly increased in PDB patients who were not currently treated, suggesting that serum measurement of macrophage colony-stimulating factor may be an indicator of disease activity. ${ }^{157}$ Although CS1 antibody, antisense oligonucleotide, and CSF1 small interfering RNA strategies have demonstrated tumor suppression capabilities in several disease (excluding PDB) and model systems, ${ }^{158,159}$ it is not yet clear enough how specific is their intervention on osteoclast formation, in bone disorders such as PDB, because other cell lineages derived from hematopoetic precursors use similar signaling pathways. ${ }^{160}$ 


\section{Conclusion}

In conclusion, nitrogen-containing bisphosphonates are currently the treatment of choice for PDB, particularly with the last generation and more powerful bisphosphonates, which have led us to aim for a more stringent definition of biochemical response to therapy. Major advances in the understanding of PDB pathophysiology in recent years could give rise to novel alternative treatment, such as targeted therapies, as a medium-term perspective for the management of PDB and other bone metabolic disorders.

\section{Acknowledgments}

LM is supported by a career award from the Fonds de la Recherche en Santé du Québec. The authors thank Mr Thomas Pornin for the preparation of Figure 1.

\section{Disclosure}

LM has served as a speaker for Amgen, Merck, and Novartis. JPB has served as a speaker and/or investigator and/or board member for Abbott, Amgen, Eli Lilly, Merck, Novartis, Pfizer, Roche, sanofi-aventis, Servier, and Warner Chilcott.

\section{References}

1. Roodman GD, Windle JJ. Paget disease of bone. J Clin Invest. 2005; 115(2):200-208.

2. Naot D, Bava U, Matthews B, et al. Differential gene expression in cultured osteoblasts and bone marrow stromal cells from patients with Paget's disease of bone. J Bone Miner Res. 2007;22(2):298-309.

3. Vellenga CJ, Pauwels EK, Bijvoet OL, Frijlink WB. Scintigraphic aspects of the recurrence of treated Paget's disease of bone. J Nucl Med. 1981;22(6):510-517.

4. Hamadouche M, Mathieu M, Topouchian V, de Pinieux G, Courpied JP. Transfer of Paget's disease from one part of the skeleton to another as a result of autogenous bone-grafting: A case report. J Bone Joint Surg Am. 2002;84-A(11):2056-2061.

5. Meunier PJ, Coindre JM, Edouard CM, Arlot ME. Bone histomorphometry in Paget's disease. Quantitative and dynamic analysis of pagetic and nonpagetic bone tissue. Arthritis Rheum. 1980;23(10):1095-1103.

6. Eekhoff ME, van der Klift M, Kroon HM, et al. Paget's disease of bone in The Netherlands: A population-based radiological and biochemical survey - the Rotterdam Study. J Bone Miner Res. 2004;19(4):566-570.

7. Rogers J, Jeffrey DR, Watt I. Paget's disease in archeological population. J Bone Miner Res. 2002;17(6):1127-1134.

8. Waldron HA. Recalculation of secular trends in Paget's disease. J Bone Miner Res. 2004;19(3):523.

9. Van Staa TP, Selby P, Leufkens HG, Lyles K, Sprafka JM, Cooper C. Incidence and natural history of Paget's disease of bone in England and Wales. J Bone Miner Res. 2002;17(3):465-471.

10. Selby PL, Davie MW, Ralston SH, Stone MD. Guidelines on the management of Paget's disease of bone. Bone. 2002;31(3):366-373.

11. Rousiere M, Michou L, Cornelis F, Orcel P. Paget's disease of bone. Best Pract Res Clin Rheumatol. 2003;17(6):1019-1041.

12. Seton M, Moses AM, Bode RK, Schwartz C. Paget's disease of bone: The skeletal distribution, complications and quality of life as perceived by patients. Bone. 2011;48(2):281-285.

13. Rebel A, Malkani K, Basle M. [Nuclear anomalies in osteoclasts in Paget's bone disease]. Nouv Presse Med. 1974;3(20):1299-1301. French.
14. Rebel A, Malkani K, Basle M, Bregeon C. Osteoclast ultrastructure in Paget's disease. Calcif Tissue Res. 1976;2:187-199.

15. Gordon MT, Anderson DC, Sharpe PT. Canine distemper virus localised in bone cells of patients with Paget's disease. Bone. 1991;12(3): 195-201.

16. Gordon MT, Mee AP, Anderson DC, Sharpe PT. Canine distemper virus transcripts sequenced from pagetic bone. Bone Miner. 1992;19(2): 159-174.

17. Mee AP, Dixon JA, Hoyland JA, Davies M, Selby PL, Mawer EB. Detection of canine distemper virus in $100 \%$ of Paget's disease samples by in situ-reverse transcriptase-polymerase chain reaction. Bone. 1998; 23(2):171-175

18. Hoyland JA, Dixon JA, Berry JL, Davies M, Selby PL, Mee AP. A comparison of in situ hybridisation, reverse transcriptase-polymerase chain reaction (RT-PCR) and in situ-RT-PCR for the detection of canine distemper virus RNA in Paget's disease. J Virol Methods. 2003;109(2): 253-259.

19. Reddy SV, Singer FR, Roodman GD. Bone marrow mononuclear cells from patients with Paget's disease contain measles virus nucleocapsid messenger ribonucleic acid that has mutations in a specific region of the sequence. J Clin Endocrinol Metab. 1995;80(7):2108-2111.

20. Friedrichs WE, Reddy SV, Bruder JM, et al. Sequence analysis of measles virus nucleocapsid transcripts in patients with Paget's disease. J Bone Miner Res. 2002;17(1):145-151.

21. Cody JD, Singer FR, Roodman GD, et al. Genetic linkage of Paget disease of the bone to chromosome 18q. Am J Hum Genet. 1997;61(5): $1117-1122$.

22. Ralston SH, Afzal MA, Helfrich MH, et al. Multicenter blinded analysis of RT-PCR detection methods for paramyxoviruses in relation to Paget's disease of bone. J Bone Miner Res. 2007;22(4):569-577.

23. Merlotti D, Gennari L, Galli B, et al. Characteristics and familial aggregation of Paget's disease of bone in Italy. $J$ Bone Miner Res. 2005;20(8):1356-1364.

24. Seton M, Choi HK, Hansen MF, Sebaldt RJ, Cooper C. Analysis of environmental factors in familial versus sporadic Paget's disease of bone - the New England Registry for Paget's Disease of Bone. J Bone Miner Res. 2003;18(8):1519-1524.

25. Lopez-Abente G, Morales-Piga A, Elena-Ibanez A, Rey-Rey JS, Corres-Gonzalez J. Cattle, pets, and Paget's disease of bone. Epidemiology. 1997;8(3):247-251.

26. Cundy T. Is the prevalence of Paget's disease of bone decreasing? J Bone Miner Res. 2006;21 Suppl 2:P9-P13.

27. Cooper C, Harvey NC, Dennison EM, van Staa TP. Update on the epidemiology of Paget's disease of bone. J Bone Miner Res. 2006; 21 Suppl 2:P3-P8.

28. Ralston SH, Langston AL, Reid IR. Pathogenesis and management of Paget's disease of bone. Lancet. 2008;372(9633):155-163.

29. Gennari L, Di Stefano M, Merlotti D, et al. Prevalence of Paget's disease of bone in Italy. J Bone Miner Res. 2005;20(10):1845-1850.

30. Rendina D, Gennari L, De Filippo G, et al. Evidence for increased clinical severity of familial and sporadic Paget's disease of bone in Campania, southern Italy. J Bone Miner Res. 2006;21(12):1828-1835.

31. Haddaway MJ, Davie MW, McCall IW, Howdle S. Effect of age and gender on the number and distribution of sites in Paget's disease of bone. Br J Radiol. 2007;80(955):532-536.

32. Josse RG, Hanley DA, Kendler D, Ste-Marie LG, Adachi JD, Brown J. Diagnosis and treatment of Paget's disease of bone. Clin Invest Med. 2007;30(5):E210-E223

33. Meunier PJ, Salson C, Delmas PD. [Skeletal distribution and biological markers of Paget's disease]. Rev Prat. 1989;39(13):1125-1128. French.

34. Kanis JA. Biochemical and endocrine aspects of Paget's disease. In: Kanis JA, editor. Pathophysiology and Treatment of Paget's Disease of Bone. 2nd ed. London: Martin Dunitz Ltd; 1998.

35. Lyles KL, Siris ES, Singer FR, Meunier PJ. A clinical approach to diagnosis and management of Paget's disease of bone. J Bone Miner Res. 2001;16(8):1379-1387. 
36. Reid IR, Davidson JS, Wattie D, et al. Comparative responses of bone turnover markers to bisphosphonate therapy in Paget's disease of bone. Bone. 2004:35(1):224-230.

37. Alvarez L, Guanabens N, Peris P, et al. Usefulness of biochemical markers of bone turnover in assessing response to the treatment of Paget's disease. Bone. 2001;29(5):447-452.

38. Alexandersen P, Peris P, Guanabens N, et al. Non-isomerized C-telopeptide fragments are highly sensitive markers for monitoring disease activity and treatment efficacy in Paget's disease of bone. J Bone Miner Res. 2005;20(4):588-595.

39. Shankar S, Hosking DJ. Biochemical assessment of Paget's disease of bone. J Bone Miner Res. 2006;21 Supp1 2:P22-P27.

40. Magnusson P, Davie MW, Sharp CA. Circulating and tissue-derived isoforms of bone alkaline phosphatase in Paget's disease of bone. Scand J Clin Lab Invest. 2010;70(2):128-135.

41. Delmas PD, Demiaux B, Malaval L, Chapuy MC, Meunier PJ. Serum bone GLA-protein is not a sensitive marker of bone turnover in Paget's disease of bone. Calcif Tissue Int. 1986;38(1):60-61.

42. Reid IR, Davidson JS, Wattie D, et al. Comparative responses of bone turnover markers to bisphosphonate therapy in Paget's disease of bone. Bone. 2004;35(1):224-230.

43. Renier JC, Fanello S, Rodriguez N, Audran M. Current prevalence of Paget's disease of bone in a region of France (Anjou). Rev Rhum Engl Ed. 1995;62(9):571-575.

44. Meunier PJ, Salson C, Mathieu L, et al. Skeletal distribution and biochemical parameters of Paget's disease. Clin Orthop. 1987;217: 37-44.

45. Daroszewska A, Ralston SH. Mechanisms of disease: Genetics of Paget's disease of bone and related disorders. Nat Clin Pract Rheumatol. 2006;2(5):270-277.

46. Morales-Piga AA, Rey-Rey JS, Corres-Gonzalez J, Garcia-Sagredo JM, Lopez-Abente G. Frequency and characteristics of familial aggregation of Paget's disease of bone. J Bone Miner Res. 1995;10(4):663-670.

47. Siris ES, Ottman R, Flaster E, Kelsey JL. Familial aggregation of Paget's disease of bone. J Bone Miner Res. 1991;6(5):495-500.

48. Laurin N, Brown JP, Lemainque A, et al. Paget disease of bone: Mapping of two loci at 5q35-qter and 5q31. Am J Hum Genet. 2001; 69(3):528-543.

49. Michou L, Collet C, Laplanche JL, Orcel P, Cornelis F. Genetics of Paget's disease of bone. Joint Bone Spine. 2006;73(3):243-248.

50. Fotino M, Haymovits A, Falk CT. Evidence for linkage between HLA and Paget's disease. Transplant Proc. 1977;9(4):1867-1868.

51. Hughes AE, Shearman AM, Weber JL, et al. Genetic linkage of familial expansile osteolysis to chromosome 18q. Hum Mol Genet. 1994;3(2): 359-361.

52. Kovach MJ, Waggoner B, Leal SM, et al. Clinical delineation and localization to chromosome 9p13.3-p12 of a unique dominant disorder in four families: Hereditary inclusion body myopathy, Paget disease of bone, and frontotemporal dementia. Mol Genet Metab. 2001;74(4):458-475.

53. Sparks AB, Peterson SN, Bell C, et al. Mutation screening of the TNFRSF11A gene encoding receptor activator of NF kappa B (RANK) in familial and sporadic Paget's disease of bone and osteosarcoma. Calcif Tissue Int. 2001;68(3):151-155.

54. Wuyts W, Van Wesenbeeck L, Morales-Piga A, et al. Evaluation of the role of RANK and OPG genes in Paget's disease of bone. Bone. 2001;28(1):104-107.

55. Albagha OM, Visconti MR, Alonso N, et al. Genome-wide association study identifies variants at CSF1, OPTN and TNFRSF11A as genetic risk factors for Paget's disease of bone. Nat Genet. 2010;42(6):520-524.

56. Hocking LJ, Herbert CA, Nicholls RK, et al. Genomewide search in familial Paget disease of bone shows evidence of genetic heterogeneity with candidate loci on chromosomes 2q36, 10p13, and 5q35. Am J Hum Genet. 2001;69(5):1055-1061.

57. Laurin N, Brown JP, Morissette J, Raymond V. Recurrent mutation of the gene encoding sequestosome 1 (SQSTM1/p62) in Paget disease of bone. Am J Hum Genet. 2002;70(6):1582-1528.
58. Hocking LJ, Lucas GJ, Daroszewska A, et al. Domain-specific mutations in sequestosome 1 (SQSTM1) cause familial and sporadic Paget's disease. Hum Mol Genet. 2002;11(22):2735-2739.

59. Lucas GJ, Riches PL, Hocking LJ, et al. Identification of a major locus for Paget's disease on chromosome 10p13 in families of British descent. J Bone Miner Res. 2008;23(1):58-63.

60. Good DA, Busfield F, Fletcher BH, et al. Linkage of Paget disease of bone to a novel region on human chromosome 18q23. Am J Hum Genet. 2002;70(2):517-525.

61. Good DA, Busfield F, Fletcher BH, et al. Identification of SQSTM1 mutations in familial Paget's disease in Australian pedigrees. Bone. 2004;35(1):277-282.

62. Daroszewska A, Hocking LJ, McGuigan FE, et al. Susceptibility to Paget's disease of bone is influenced by a common polymorphic variant of osteoprotegerin. J Bone Miner Res. 2004;19(9):1506-1511.

63. Beyens G, Daroszewska A, de Freitas F, et al. Identification of sex-specific associations between polymorphisms of the osteoprotegerin gene, TNFRSF11B, and Paget's disease of bone. J Bone Miner Res. 2007;22(7):1062-1071.

64. Watts GD, Wymer J, Kovach MJ, et al. Inclusion body myopathy associated with Paget disease of bone and frontotemporal dementia is caused by mutant valosin-containing protein. Nat Genet. 2004;36(4): $377-381$.

65. Lucas GJ, Mehta SG, Hocking LJ, et al. Evaluation of the role of valosin-containing protein in the pathogenesis of familial and sporadic Paget's disease of bone. Bone. 2006;38(2):280-285.

66. Chung PY, Beyens G, Boonen S, et al. The majority of the genetic risk for Paget's disease of bone is explained by genetic variants close to the CSF1, OPTN, TM7SF4, and TNFRSF11A genes. Hum Genet. 2010; 128(6):615-626.

67. Morissette J, Laurin N, Brown JP. Sequestosome 1: Mutation frequencies, haplotypes, and phenotypes in familial Paget's disease of bone. J Bone Miner Res. 2006;21 Suppl 2:P38-P44.

68. Cundy T, Bolland M. Paget disease of bone. Trends Endocrinol Metab. 2008;19(7):246-253.

69. Collet C, Michou L, Audran M, et al. Paget's disease of bone in the French population: Novel SQSTM1 mutations, functional analysis, and genotype-phenotype correlations. J Bone Miner Res. 2007;22(2): 310-317.

70. Michou L, Morissette J, Gagnon ER, et al. Novel SQSTM1 mutations in patients with Paget's disease of bone in an unrelated multiethnic American population. Bone. 2011;48(3):456-460.

71. Beyens G, Van Hul E, Van Driessche K, et al. Evaluation of the role of the SQSTM1 gene in sporadic Belgian patients with Paget's disease. Calcif Tissue Int. 2004;75(2):144-152.

72. Cavey JR, Ralston SH, Sheppard PW, et al. Loss of ubiquitin binding is a unifying mechanism by which mutations of SQSTM1 cause Paget's disease of bone. Calcif Tissue Int. 2006;78(5):271-277.

73. Najat D, Garner T, Hagen T, et al. Characterization of a non-UBA domain missense mutation of sequestosome 1 (SQSTM1) in Paget's disease of bone. J Bone Miner Res. 2009;24(4):632-642.

74. Layfield R. The molecular pathogenesis of Paget disease of bone. Expert Rev Mol Med. 2007;9(27):1-13.

75. Duran A, Serrano M, Leitges M, et al. The atypical PKC-interacting protein p62 is an important mediator of RANK-activated osteoclastogenesis. Dev Cell. 2004;6(2):303-309.

76. Chamoux E, Couture J, Bisson M, Morissette J, Brown JP, Roux S. The p62 P392L mutation linked to Paget's disease induces activation of human osteoclasts. Mol Endocrinol. 2009;23(10):1668-1680.

77. Kerscher O, Felberbaum R, Hochstrasser M. Modification of proteins by ubiquitin and ubiquitin-like proteins. Annu Rev Cell Dev Biol. 2006;22: 159-180.

78. Reinstein E, Ciechanover A. Narrative review. Protein degradation and human diseases: The ubiquitin connection. Ann Intern Med. 2006; 145(9):676-684.

79. Sumpter R Jr, Levine B. Selective autophagy and viruses. Autophagy. 2011;7(3). [Epub ahead of print]. 
80. Shelly S, Lukinova N, Bambina S, Berman A, Cherry S. Autophagy is an essential component of Drosophila immunity against vesicular stomatitis virus. Immunity. 2009;30(4):588-598.

81. Seglen PO, Bohley P. Autophagy and other vacuolar protein degradation mechanisms. Experientia. 1992;48(2):158-172.

82. Cuervo AM. Autophagy: In sickness and in health. Trends Cell Biol. 2004;14(2):70-77.

83. Harada M, Kumemura H, Omary MB, et al. Proteasome inhibition induces inclusion bodies associated with intermediate filaments and fragmentation of the Golgi apparatus. Exp Cell Res. 2003; 288(1):60-69.

84. Komatsu M, Waguri S, Chiba T, et al. Loss of autophagy in the central nervous system causes neurodegeneration in mice. Nature. 2006; 441(7095):880-884.

85. Zatloukal K, French SW, Stumptner C, et al. From Mallory to MalloryDenk bodies: What, how and why? Exp Cell Res. 2007;313(10): 2033-2049.

86. Rima BK, Duprex WP. Molecular mechanisms of measles virus persistence. Virus Res. 2005;111(2):132-147.

87. Reddy SV, Menaa C, Singer FR, et al. Measles virus nucleocapsid transcript expression is not restricted to the osteoclast lineage in patients with Paget's disease of bone. Exp Hematol. 1999;27(10): $1528-1532$.

88. Mottet G, Curran J, Roux L. Intracellular stability of nonreplicating paramyxovirus nucleocapsids. Virology. 1990;176(1):1-7.

89. Griffin DE. Measles virus-induced suppression of immune responses. Immunol Rev. 2010;236:176-189.

90. Ehrlich LA, Roodman GD. The role of immune cells and inflammatory cytokines in Paget's disease and multiple myeloma. Immunol Rev. 2005;208:252-266.

91. Murabayashi N, Kurita-Taniguchi M, Ayata M, Matsumoto M, Ogura H, Seya T. Susceptibility of human dendritic cells (DCs) to measles virus (MV) depends on their activation stages in conjunction with the level of CDw150: Role of toll stimulators in DC maturation and MV amplification. Microbes Infect. 2002;4(8):785-794.

92. Jin Z, Li Y, Pitti R, et al. Cullin 3-based polyubiquitination and p62-dependent aggregation of caspase- 8 mediate extrinsic apoptosis signaling. Cell. 2009;137(4):721-735.

93. Goode A, Layfield R. Recent advances in understanding the molecular basis of Paget disease of bone. J Clin Pathol. 2010;63(3):199-203.

94. Selby PL, Davies M, Mee AP. Canine distemper virus induces human osteoclastogenesis through NF-kappaB and sequestosome 1/P62 activation. J Bone Miner Res. 2006;21(11):1750-1756.

95. Brandwood CP, Hoyland JA, Hillarby MC, et al. Apoptotic gene expression in Paget's disease: A possible role of Bcl-2. J Pathol. 2003; 201(3):504-512.

96. Kukita A, Chenu C, McManus LM, Mundy GR, Roodman GD. Atypical multinucleated cells form in long-term marrow cultures from patients with Paget's disease. J Clin Invest. 1990;85(4):1280-1286.

97. Kurihara N, Reddy SV, Araki N, et al. Role of TAFII-17, a VDR binding protein, in the increased osteoclast formation in Paget's disease. J Bone Miner Res. 2004;19(7):1154-1164.

98. Menaa C, Reddy SV, Kurihara N, et al. Enhanced RANK ligand expression and responsivity of bone marrow cells in Paget's disease of bone. J Clin Invest. 2000;105(12):1833-1838.

99. Roodman GD, Kurihara N, Ohsaki Y, et al. Interleukin 6. A potential autocrine/paracrine factor in Paget's disease of bone. J Clin Invest. 1992;89(1):46-52.

100. Kurihara N, Reddy SV, Menaa C, Anderson D, Roodman GD. Osteoclasts expressing the measles virus nucleocapsid gene display a pagetic phenotype. J Clin Invest. 2000;105(5):607-614.

101. Kurihara N, Hiruma Y, Yamana K, et al. Contributions of the measles virus nucleocapsid gene and the SQSTM1/p62(P392L) mutation to Paget's disease. Cell Metab. 2011;13(1):23-34.

102. Kurihara N, Zhou H, Reddy SV, et al. Expression of measles virus nucleocapsid protein in osteoclasts induces Paget's disease-like bone lesions in mice. J Bone Miner Res. 2006;21(3):446-455.
103. Ralston SH. Pathogenesis of Paget's disease of bone. Bone. 2008;43(5):819-825.

104. Kurihara N, Hiruma Y, Zhou H, et al. Mutation of the sequestosome 1 (p62) gene increases osteoclastogenesis but does not induce Paget disease. J Clin Invest. 2007;117(1):133-142.

105. Hiruma Y, Kurihara N, Subler MA, et al. A SQSTM1/p62 mutation linked to Paget's disease increases the osteoclastogenic potential of the bone microenvironment. Hum Mol Genet. 2008;17(23): 3708-3719.

106. Roodman GD. Insights into the pathogenesis of Paget's disease. Ann N Y Acad Sci. 2010;1192:176-180.

107. Lyles KW, Siris ES, Singer FR, Meunier PJ. A clinical approach to diagnosis and management of Paget's disease of bone. J Bone Miner Res. 2001;16(8):1379-1387.

108. Takata S, Hashimoto J, Nakatsuka K, et al. Guidelines for diagnosis and management of Paget's disease of bone in Japan. J Bone Miner Metab. 2006;24(5):359-367.

109. Adami S, Bartolozzi P, Brandi ML, et al. [Italian guidelines for the diagnosis and treatment of Paget's disease of bone]. Reumatismo. 2007;59(2):153-168. Italian.

110. Wermers RA, Tiegs RD, Atkinson EJ, Achenbach SJ, Melton LJ 3rd. Morbidity and mortality associated with Paget's disease of bone: A population-based study. J Bone Miner Res. 2008;23(6):819-825.

111. Singer FR. Paget disease: When to treat and when not to treat. Nat Rev Rheumatol. 2009;5(9):483-489.

112. Meunier PJ, Vignon E. Therapeutic strategy in Paget's disease of bone. Bone. 1999;17(Suppl 5):489S-491S.

113. Brown JP, Chines AA, Myers WR, Eusebio RA, Ritter-Hrncirik C, Hayes CW. Improvement of pagetic bone lesions with risedronate treatment: A radiologic study. Bone. 2000;26(3):263-267.

114. Brown JP, Hosking DJ, Ste-Marie L, et al. Risedronate, a highly effective, short-term oral treatment for Paget's disease: A dose-response study. Calcif Tissue Int. 1999;64(2):93-99.

115. Brown JP. Metabolic bone diseases: Treating Paget disease: when matters more than how. Nat Rev Rheumatol. 2009;5(12): 663-665.

116. Langston AL, Campbell MK, Fraser WD, MacLennan GS, Selby PL, Ralston SH. Randomized trial of intensive bisphosphonate treatment versus symptomatic management in Paget's disease of bone. J Bone Miner Res. 2010;25(1):20-31.

117. Reid IR, Cundy T, Bolland MJ, Grey A. Response to publication of PRISM trial. J Bone Miner Res. 2010;25(6):1463-1464.

118. Whitson HE, Lobaugh B, Lyles KW. Severe hypocalcemia following bisphosphonate treatment in a patient with Paget's disease of bone. Bone. 2006;39(4):954-958.

119. Reid IR, Hosking DJ. Bisphosphonates in Paget's disease. Bone. September 9, 2010. [Epub ahead of print].

120. Chambers TJ, Magnus CJ. Calcitonin alters behaviour of isolated osteoclasts. J Pathol. 1982;136(1):27-39.

121. Fleisch H, Russell RG, Francis MD. Diphosphonates inhibit hydroxyapatite dissolution in vitro and bone resorption in tissue culture and in vivo. Science. 1969;165(899):1262-1264.

122. Rogers MJ. New insights into the molecular mechanisms of action of bisphosphonates. Curr Pharm Des. 2003;9(32):2643-2658.

123. Miller PD, Brown JP, Siris ES, Hoseyni MS, Axelrod DW, Bekker PJ. A randomized, double-blind comparison of risedronate and etidronate in the treatment of Paget's disease of bone. Paget's Risedronate/ Etidronate Study Group. Am J Med. 1999;106(5):513-520.

124. Gray RE, Yates AJ, Preston CJ, Smith R, Russell RG, Kanis JA. Duration of effect of oral diphosphonate therapy in Paget's disease of bone. Q J Med. 1987;64(245):755-767.

125. Fraser WD, Stamp TC, Creek RA, Sawyer JP, Picot C. A double-blind, multicentre, placebo-controlled study of tiludronate in Paget's disease of bone. Postgrad Med J. 1997;73(862):496-502.

126. Anderson DC, Richardson PC, Brown JK, et al. Intravenous pamidronate: Evolution of an effective treatment strategy. Semin Arthritis Rheum. 1994;23(4):273-275. 
127. Siris E, Weinstein RS, Altman R, et al. Comparative study of alendronate versus etidronate for the treatment of Paget's disease of bone. J Clin Endocrinol Metab. 1996;81(3):961-967.

128. Reid IR, Miller P, Lyles K, et al. Comparison of a single infusion of zoledronic acid with risedronate for Paget's disease. $N$ Engl J Med. 2005;353(9):898-908.

129. Walsh JP, Ward LC, Stewart GO, et al. A randomized clinical trial comparing oral alendronate and intravenous pamidronate for the treatment of Paget's disease of bone. Bone. 2004;34(4):747-754.

130. Merlotti D, Gennari L, Martini G, et al. Comparison of different intravenous bisphosphonate regimens for Paget's disease of bone. J Bone Miner Res. 2007;22(10):1510-1517.

131. Hooper M, Faustino A, Reid IR, et al. Randomized, active-controlled study of once-weekly alendronate $280 \mathrm{mg}$ high dose oral buffered solution for treatment of Paget's disease. Osteoporos Int. 2009;20(1): $141-150$.

132. Hosking D, Lyles K, Brown JP, et al. Long-term control of bone turnover in Paget's disease with zoledronic acid and risedronate. $J$ Bone Miner Res. 2007;22(1):142-148.

133. Reid I, Lyles KW, Su G, et al. Long-term efficacy of zoledronic acid compared with risedronate in Paget's disease Bone. 2010;47 Suppl 1:OC21.

134. Papapoulos SE, Eekhoff ME, Zwinderman AH. Acquired resistance to bisphosphonates in Paget's disease of bone. J Bone Miner Res. 2006;21 Suppl 2:P88-P91.

135. Pazianas M, Abrahamsen B. Safety of bisphosphonates. Bone. January 12, 2011. [Epub ahead of print].

136. Hosking DJ. Prediction and assessment of the response of Paget's disease to bisphosphonate treatment. Bone. 1999;24(Suppl 5):69S-71S.

137. Ebert R, Zeck S, Krug R, et al. Pulse treatment with zoledronic acid causes sustained commitment of bone marrow derived mesenchymal stem cells for osteogenic differentiation. Bone. 2009;44(5):858-864.

138. Green J, Clezardin P. The molecular basis of bisphosphonate activity: A preclinical perspective. Semin Oncol. 2010;37 Suppl 1:S3-S11.

139. Romas E. Clinical applications of RANK-ligand inhibition. Intern Med J. 2009;39(2):110-116.

140. Crockett JC, Mellis DJ, Scott DI, Helfrich MH. New knowledge on critical osteoclast formation and activation pathways from study of rare genetic diseases of osteoclasts: Focus on the RANK/RANKL axis. Osteoporos Int. 2011;22(1):1-20.

141. Roodman GD. Interleukin-6: An osteotropic factor? J Bone Miner Res. 1992;7(5):475-478.

142. Corral-Gudino L, del Pino-Montes J, Garcia-Aparicio J, AlonsoGarrido M, Gonzalez-Sarmiento R. Paget's disease of bone is not associated with common polymorphisms in interleukin- 6 , interleukin- 8 and tumor necrosis factor alpha genes. Cytokine. 2010;52(3):146-150.

143. Nishimoto N, Miyasaka N, Yamamoto K, Kawai S, Takeuchi T, Azuma J. Long-term safety and efficacy of tocilizumab, an anti-IL-6 receptor monoclonal antibody, in monotherapy, in patients with rheumatoid arthritis (the STREAM study): Evidence of safety and efficacy in a 5-year extension study. Ann Rheum Dis. 2009;68(10): $1580-1584$.
144. Dayer JM, Choy E. Therapeutic targets in rheumatoid arthritis: The interleukin-6 receptor. Rheumatology (Oxford). 2010;49(1):15-24.

145. Marshall MJ, Evans SF, Sharp CA, Powell DE, McCarthy HS, Davie MW. Increased circulating Dickkopf-1 in Paget's disease of bone. Clin Biochem. 2009;42(10-11):965-969.

146. McCarthy HS, Marshall MJ. Dickkopf-1 as a potential therapeutic target in Paget's disease of bone. Expert Opin Ther Targets. 2010;14(2): 221-230.

147. Roodman GD. Studies in Paget's disease and their relevance to oncology. Semin Oncol. 2001;28(4 Suppl 11):15-21.

148. Roodman GD. Osteoblast function in myeloma. Bone. 2011;48(1) 135-140.

149. Zhou FL, Meng S, Zhang WG, et al. Peptide-based immunotherapy for multiple myeloma: Current approaches. Vaccine. 2010;28(37): 5939-5946.

150. Liggett A, Crawford LJ, Walker B, Morris TC, Irvine AE. Methods for measuring proteasome activity: Current limitations and future developments. Leuk Res. 2010;34(11):1403-1409.

151. Chanan-Khan AA, Borrello I, Lee KP, Reece DE. Development of target-specific treatments in multiple myeloma. $\mathrm{Br} J$ Haematol. 2010;151(1):3-15.

152. Roodman GD. Novel targets for myeloma bone disease. Expert Opin Ther Targets. 2008;12(11):1377-1387.

153. Deal C. Future therapeutic targets in osteoporosis. Curr Opin Rheumatol. 2009;21(4):380-385.

154. Michou L, Chamoux E, Couture J, Morissette J, Brown JP, Roux S. Gene expression profile in osteoclasts from patients with Paget's disease of bone. Bone. 2010;46(3):598-603.

155. Nagy ZB, Gergely P, Donath J, Borgulya G, Csanad M, Poor G. Gene expression profiling in Paget's disease of bone: Upregulation of interferon signaling pathways in pagetic monocytes and lymphocytes. J Bone Miner Res. 2008;23(2):253-259.

156. Bruzzaniti A, Baron R. Molecular regulation of osteoclast activity. Rev Endocr Metab Disord. 2006;7(1-2):123-139.

157. Neale SD, Schulze E, Smith R, Athanasou NA. The influence of serum cytokines and growth factors on osteoclast formation in Paget's disease. Q J Med. 2002;95(4):233-240.

158. Aharinejad S, Paulus P, Sioud M, et al. Colony-stimulating factor-1 blockade by antisense oligonucleotides and small interfering RNAs suppresses growth of human mammary tumor xenografts in mice. Cancer Res. 2004;64(15):5378-5384.

159. Cheng H, Clarkson PW, Gao D, Pacheco M, Wang Y, Nielsen TO Therapeutic antibodies targeting CSF1 impede macrophage recruitment in a xenograft model of tenosynovial giant cell tumor. Sarcoma. 2010;2010:174528

160. Vaananen K. Mechanism of osteoclast mediated bone resorption rationale for the design of new therapeutics. Adv Drug Deliv Rev. 2005;57(7):959-971.

\section{Publish your work in this journal}

Drug Design, Development and Therapy is an international, peerreviewed open-access journal that spans the spectrum of drug design and development through to clinical applications. Clinical outcomes, patient safety, and programs for the development and effective, safe, and sustained use of medicines are a feature of the journal, which

\section{Dovepress}

has also been accepted for indexing on PubMed Central. The manuscript management system is completely online and includes a very quick and fair peer-review system, which is all easy to use. Visit http://www.dovepress.com/testimonials.php to read real quotes from published authors. 